Editorial

\title{
The interaction between intermittent renewable energy and the electricity, heating and transport sectors
}

In a global perspective, it is essential that the world transfers from fossil fuels to renewable energy sources in order to minimise climate change effects. As a part of such transition energy savings are also important, as they can decrease production costs effectively. The nature of such a change is that it has to be implemented on a local level. Energy saving technologies are placed with the demand decrease and renewable energy is typically distributed where the resources are. In some parts of the world, energy savings have resulted in a stabilisation of the energy demands, however in the world as such, demands are still increasing in buildings, transport and industry. Although the demand has increased approx. 32\% overall, the share of renewable energy has increased from $12.7 \%$ in 1990 to $13 \%$ in 2010 [1], in this way demonstrating that renewables can effectively cope with the world energy requirements - even in a context characterized by a continuously increasing demand. Even in the current financial crisis, renewable energy is expanding heavily [2]. The most used renewable energy is biomass; however there has been a significant increase in wind power and in photovoltaic in the last ten years. Such development in the intermittent renewable energy sources requires knowledge about the interaction between supply and demand sides of energy.

At the 6th Dubrovnik Conference on Sustainable Development of Energy, Water and Environmental Systems, September 25-29 2011, in Dubrovnik, Croatia, these issues were addressed among others. The conference was dedicated to research concerning methods, policies and technologies for increasing the sustainable development as well as methods for assessing and measuring sustainability of development, regarding energy, transport, water and environment systems and their many combinations. At the conference 418 scientists from 55 countries representing six continents participated. In this Special Issue the interaction between sectors and renewable energy systems through selected papers from this conference is addressed from a range of technical system analyses to environmental and economic feasibility.

Buildings account for a substantial part of the global energy supply. Approximately 35\% of the world's energy demand is in buildings of which approximately $75 \%$ is heating and hot water demand [3]. In such a perspective the design and interaction between buildings and the energy systems surrounding and supporting it becomes important in the evaluations of which heating systems are able to facilitate these technological changes. The required technological changes are different in the renovation of existing buildings than in new buildings, however in both cases the concept of zero emission buildings and improvements in energy efficiency cannot be seen isolated from the renewable energy sources and the energy system surrounding them. In some cases individual solutions are most suitable but in other cases district heating is a more fuel and cost efficient solution. Energy savings and system integration with district heating can be beneficial in the existing building. In Wada et al. [4] the potential for reductions in greenhouse gas emissions is calculated to be very significant on a global level and policy makers are aware of this and hence the standards for energy efficiency is increasing for new buildings as in the case in the UK is pointed out by Pan \& Garmston [5]. In Nielsen \& Möller [6] the future of district heating is examined in the light of net zero emission building and the main findings are that excess heat from these buildings can benefit district heating systems by decreasing the production from production units utilizing combustible fuels. In the existing building stock there are benefits and potentials for expanding district heating in several cases, such as the Croatian case in Loncar \& Ridjan [7], the Italian case in Verda et al. [8] and the Danish case in Münster et al. [9] taking into consideration energy savings.

In Stutterecker \& Blümel [10] renovation shows how a single larger building can approach passive house standards and the knowledge of how building behave should be more certain as illustrated in Simões \& Serra [11] and Sorrentino et al. [12]. However when looking at the transition of the entire energy system, such as in the example of Macedonia by Cosic et al. [13] and Taseska et al. [14] as well as the case of the UK by Alderson et al. [15], it is clear that such technologies on the individual houses have to be seen in the perspective of the energy system. In Ban et al. [16] the example of cooling storage is used in such interaction, in Milan et al. [17] on-site PV production and heat pumps for the heat consumption is used and the electricity demand and electric heating is used in Arghira et al. [18] and Fitzgerald et al. [19]. There are however larger systems integration and storage options such as pumped hydro analysed in Pérez-Díaz et al. [20], again however the heating sector can make a large contribution using combined heat and power (CHP) and large heat pumps such as pointed out in the German case in Kusch et al. [21]. In fact both system integration using CHP, large heat pumps, and other renewable energy resources in district heating can reduce the biomass consumption significantly by using intermittent renewable energy sources in $100 \%$ renewable energy systems as analysed in Mathiesen et al. [22]. Several case studies evaluate CHP in different context such as Danon et al. [23], Radulovic et al. [24] and Heinz \& Henkel 
[25]. The benefits of district heating are as mentioned, that the system can use different sources such e.g. waste, biogas, industrial waste heat, geothermal as shown in Wang et al. [26], Schneider et al. [27], Börjesson \& Ahlgren [28], Öhman [29] and Kalogirou et al. [30]. In systems without CHP the replacement of fossil fuels in power plants such as illustrated in the Brazilian, Nepalese and Spanish cases in Khatiwada et al. [31] and Royo et al. [32] may especially put pressure on the biomass resource.

In such perspectives intermittent renewable energy sources should be expanded and developed. Wind has had a major development in Europe and the Unites States, however China is now also focussing heavily on this development. In Hong \& Möller [33] a further future potential of going off-shore is shown to be able to cover substantial amounts of the energy supply. Further wind development will put demands on improving the distribution and transmission grids. For long distance transport ultra-HighVoltages direct current may be feasible as pointed out in Humpert [34], while the wind turbines may also contribute to frequency control as analysed by Camblong et al. [35]. Intermittent renewable energy as wind and PV still can still be further improved as illustrated by Jiang et al. and Kalogirou [36,37], however energy market are important to ensure that power plants and CHP do not produce when there are intermittent renewable energy in the grid, and even though there has been focus on these for many years in e.g. EU there are still improvements to be made as pointed out by Moreno et al. [38].

In Denmark, the current coverage of wind power in the electricity grid is app. $28 \%$ in 2011 and the plan is to reach $50 \%$ of coverage by 2020 . Most plans are very large off-shore parks, however in Müller et al. [39] the potential for going off-shore in a smaller wind parks is shown. These could have lower local impacts on the environment. In fact the local level is rather important, as reductions in consumption and the distributed nature of renewable energy is dispersed and has to be accepted locally. In Brandoni \& Polonara [40] and Müller et al. [41] this is illustrated for a number of local strategies in Italy and for a number of Islands. When renewable energy penetrate the energy system other sectors than the heating system may be important to be integrated.

In Ajanovic et al. [42] the potential for more energy efficient vehicles is shown, however in the future, the importance of integrating the transport sector with the rest of the energy system is important. Here electric vehicles can contribute to the integration of renewable energy by replacing combustion technologies and charging in situations with wind power. This is analysed with different electric vehicles penetrations and charging strategies in Hedegaard et al. and Metz \& Doetsch [43,44]. Electric vehicles however can only cover lighter transport, and truck as well as aviation and ships will need biofuels in order to transfer to renewable energy such as bio-methanol, bio-ethanol and bio-diesel in Ko et al. [45], Zhang et al. [46] and Hájek et al. [47].

A long term perspective is necessary in the strategies for transition to more renewable energy and energy savings, such as illustrated in Irsag et al. [48] by potential long term saving in the Croatian increasing tourism sector and a life cycle perspective in the case of green roofs in Peri et al. [49]. The long term perspective is especially important when coupling this with the current economic situation as pointed out in the Portuguese situation by Oliveira Henriques \& Antunes [50]. The potential of having a more certain long term cost of the energy systems is substantial with renewable energy and energy savings, however this requires methodologies in developed and developing countries e.g. in Cantore and Paleta et al. [51,52] and case studies in different corners of integrated renewable energy systems described above.

\section{Conclusions and acknowledgements}

This Special issue, devoted to energy at Conference on Sustainable Development of Energy Water and Environmental Systems SDEWES 2011, provided an overview of several topics related to sustainable development. The Guest editors believe that the selected papers and addressed issues would be of interest of readers of ENERGY journal.

The Guest editors would like to thank the all reviewers who have made most valuable contribution by reviewing, commenting and advising authors. Special thanks should go to the administration staff in the ENERGY journal for their excellent support.

\section{References}

[1] International Energy Agency statistics. Renewables information; ISBN 978 92-64-17388-0; 2012.

[2] International Energy Agency. Renewable energy Medium-Term Market Report 2012. Trends and Projections to 2017.

[3] International Energy Agency. Barriers to technology diffusion: the case of solar thermal technologies. Paris: OECD/IEA; 2006.

[4] Wada Kenichi, Akimoto Keigo, Sano Fuminori, Oda Junichiro, Homma Takashi. Energy efficiency opportunities in the residential sector and their feasibility Energy 26 February 2012 ISSN: 0360-5442. http://dx.doi.org/10.1016 j.energy.2012.01.046. Available online.

[5] Pan Wei, Garmston Helen. Compliance with building energy regulations for new-build dwellings. Energy 18 July 2012 ISSN: 0360-5442. http:// dx.doi.org/10.1016/i.energy.2012.06.048. Available online.

[6] Nielsen Steffen, Möller Bernd. Excess heat production of future net zero energy buildings within district heating areas in Denmark. Energy 1 May 2012 ISSN 0360-5442. http://dx.doi.org/10.1016/i.energy.2012.04.012. Available online.

[7] Lončar D, Ridjan I. Medium term development prospects of cogeneration district heating systems in transition country - Croatian case. Energy 14 August 2012 ISSN: 0360-5442. http://dx.doi.org/10.1016/j.energy.2012.07.025. Available online.

[8] Verda Vittorio, Guelpa Elisa, Kona Albana, Russo Stefano Lo. Reduction of primary energy needs in urban areas trough optimal planning of district heating and heat pump installations. Energy 25 July 2012 ISSN: 0360-5442. http:// dx.doi.org/10.1016/j.energy.2012.07.001. Available online.

[9] Münster Marie, Morthorst Poul Erik, Larsen Helge V, Bregnbæk Lars, Werling Jesper, Lindboe Hans Henrik, et al. The role of district heating in the future Danish energy system. Energy 3 July 2012 ISSN: 0360-5442. http://dx.doi.org/10.1016/j.energy.2012.06.011. Available online.

[10] Stutterecker Werner, Blümel Ernst. Energy plus standard in buildings constructed by housing associations? Energy 12 July 2012 ISSN: 0360-5442. http://dx.doi.org/10.1016/i.energy.2012.06.044. Available online.

[11] Simões N, Serra C. Ground contact heat losses: simplified calculation method for residential buildings. Energy 7 May 2012 ISSN: 0360-5442. http:/ dx.doi.org/10.1016/j.energy.2012.04.013. Available online.

[12] Sorrentino Giancarlo, Scaccianoce Gianluca, Morale Massimo, Franzitta Vincenzo. The importance of reliable climatic data in the energy evaluation. Energy 5 May 2012 ISSN: 0360-5442. http://dx.doi.org/10.1016/ j.energy.2012.04.015. Available online.

[13] Cosi\&cacute Boris, Krajačić Goran, Duić Neven. A 100\% renewable energy system in the year 2050: the case of Macedonia. Energy 1 August 2012 ISSN: 0360-5442. http://dx.doi.org/10.1016/j.energy.2012.06.078. Available online.

[14] Taseska Verica, Markovska Natasa, Callaway John M. Evaluation of climate change impacts on energy demand. Energy 20 July 2012 ISSN: 0360-5442. http:/dx.doi.org/10.1016/i.energy.2012.06.053. Available online.

[15] Alderson Helen, Cranston Gemma R, Hammond Geoffrey P. Carbon and environmental footprinting of low carbon UK electricity futures to 2050. Energy 12 May 2012 ISSN: 0360-5442. http://dx.doi.org/10.1016/j.energy.2012.04.011. Available online.

[16] Ban Marko, Krajačić Goran, Grozdek Marino, Ćurko Tonko, Duić Neven. The role of cool thermal energy storage (CTES) in the integration of renewable energy sources (RES) and peak load reduction. Energy 9 August 2012 ISSN: 0360-5442. http://dx.doi.org/10.1016/j.energy.2012.06.070. Available online.

[17] Milan Christian, Bojesen Carsten, Nielsen Mads Pagh. A cost optimization model for $100 \%$ renewable residential energy supply systems. Energy 18 June 2012 ISSN: 0360-5442. http://dx.doi.org/10.1016/j.energy.2012.05.034. Available online.

[18] Arghira Nicoleta, Hawarah Lamis, Ploix Stéphane, Jacomino Mireille. Prediction of appliances energy use in smart homes. Energy 8 May 2012 ISSN: 0360-5442. http://dx.doi.org/10.1016/j.energy.2012.04.010. Available online.

[19] Fitzgerald Niall, Foley Aoife M, McKeogh Eamon. Integrating wind power using intelligent electric water heating. Energy 3 May 2012 ISSN: 03605442. http://dx.doi.org/10.1016/i.energy.2012.03.014. Available online.

[20] Pérez-Díaz JI, Millán R, García D, Guisández I, Wilhelmi JR. Contribution of reregulation reservoirs considering pumping capability to environmentally 
friendly hydropower operation. Energy 26 July 2012 ISSN: 0360-5442. http:// dx.doi.org/10.1016/j.energy.2012.06.071. Available online.

[21] Kusch Wolfgang, Schmidla Tim, Stadler Ingo. Consequences for district heating and natural gas grids when aiming towards $100 \%$ electricity supply with renewables. Energy 10 August 2012 ISSN: 0360-5442. http://dx.doi.org/ 10.1016/j.energy.2012.06.054. Available online.

[22] Mathiesen Brian Vad, Lund Henrik, Connolly David. Limiting biomass consumption for heating in 100\% renewable energy systems. Energy 29 August 2012 ISSN: 0360-5442. http://dx.doi.org/10.1016/j.energy.2012.07.063. Available online.

[23] Danon Gradimir, Furtula Mladen, Mandić Marija. Possibilities of implementation of CHP (combined heat and power) in the wood industry in Serbia. Energy 30 March 2012 ISSN: 0360-5442. http://dx.doi.org/10.1016/ j.energy.2012.02.073. Available online.

[24] Radulovic Dusko, Skok Srdjan, Kirincic Vedran. Cogeneration - investment dilemma. Energy 3 August 2012 ISSN: 0360-5442. http://dx.doi.org/10.1016 j.energy.2012.06.057. Available online.

[25] Heinz Boris, Henkel Johannes. Balancing wind energy and participating in electricity markets with a fuel cell population. Energy 27 July 2012 ISSN 0360-5442. http://dx.doi.org/10.1016/i.energy.2012.07.002. Available online.

[26] Wang Chaojun, He Boshu, Sun Shaoyang, Wu Ying, Yan Na, Yan Linbo, et al. Application of a low pressure economizer for waste heat recovery from the exhaust flue gas in a $600 \mathrm{MW}$ power plant. Energy 20 February 2012 ISSN: 0360-5442. http://dx.doi.org/10.1016/j.energy.2012.01.045. Available online.

[27] Schneider Daniel Rolph, Kirac Mislav, Hublin Andrea. Cost-effectiveness of GHG emission reduction measures and energy recovery from municipal waste in Croatia. Energy 2 March 2012 ISSN: 0360-5442. http://dx.doi.org/10.1016/ j.energy.2012.02.008. Available online.

[28] Börjesson Martin, Ahlgren Erik O. Cost-effective biogas utilisation - a modelling assessment of gas infrastructural options in a regional energy system. Energy 20 July 2012 ISSN: 0360-5442. http://dx.doi.org/10.1016/ j.energy.2012.06.058. Available online.

[29] Öhman Henrik. Implementation and evaluation of a low temperature waste heat recovery power cycle using $\mathrm{NH}_{3}$ in an Organic Rankine Cycle. Energy 30 March 2012 ISSN: 0360-5442. http://dx.doi.org/10.1016/ i.energy.2012.02.074. Available online.

[30] Kalogirou Soteris A, Florides Georgios A, Pouloupatis Panayiotis D Panayides Ioannis, Joseph-Stylianou Josephina, Zomeni Zomenia. Artificia neural networks for the generation of geothermal maps of ground temperature at various depths by considering land configuration. Energy 15 July 2012 ISSN: 0360-5442. http://dx.doi.org/10.1016/j.energy.2012.06.045. Available online.

[31] Khatiwada Dilip, Seabra Joaquim, Silveira Semida, Walter Arnaldo. Powe generation from sugarcane biomass - a complementary option to hydroelec tricity in Nepal and Brazil. Energy 7 April 2012 ISSN: 0360-5442. http:// dx.doi.org/10.1016/j.energy.2012.03.015. Available online.

[32] Royo Javier, Sebastián Fernando, -Galindo Daniel García, Gómez Maider Díaz Maryori. Large-scale analysis of GHG (greenhouse gas) reduction by means of biomass co-firing at country-scale: application to the Spanish case. Energy 24 July 2012 ISSN: 0360-5442. http://dx.doi.org/10.1016 j.energy.2012.06.046. Available online.

[33] Hong Lixuan, Möller Bernd. Feasibility study of China's offshore wind target by 2020. Energy 12 April 2012 ISSN: 0360-5442. http://dx.doi.org/10.1016 j.energy.2012.03.016. Available online.

[34] Humpert Christof. Long distance transmission systems for the future electricity supply - analysis of possibilities and restrictions. Energy 18 July 2012 ISSN: 0360-5442. http://dx.doi.org/10.1016/j.energy.2012.06.018. Available online.

[35] Camblong H, Nourdine S, Vechiu I, Tapia G. Control of wind turbines for fatigue loads reduction and contribution to the grid primary frequency regulation. Energy 22 June 2012 ISSN: 0360-5442. http://dx.doi.org/10.1016/ j.energy.2012.05.035. Available online.

[36] Jiang Jheng-Lun, Chang Hong-Chan, Kuo Cheng-Chien. Analysis of transient energy affection for wind farm under lightning. Energy 19 March 2012 ISSN: 0360-5442. http://dx.doi.org/10.1016/j.energy.2012.02.032. Available online.

[37] Kalogirou Soteris A. A detailed thermal model of a parabolic trough collector receiver. Energy 11 July 2012 ISSN: 0360-5442. http://dx.doi.org/10.1016 j.energy.2012.06.023. Available online.

[38] Moreno Blanca, López Ana J, García-Álvarez María Teresa. The electricity prices in the European Union. The role of renewable energies and regulatory electric market reforms. Energy 20 July 2012 ISSN: 0360-5442. http:// dx.doi.org/10.1016/j.energy.2012.06.059. Available online.

[39] Möller Bernd, Hong Lixuan, Lonsing Reinhard, Hvelplund Frede. Evaluation of offshore wind resources by scale of development. Energy 11 February 2012 ISSN: 0360-5442. http://dx.doi.org/10.1016/j.energy.2012.01.029. Available online.

[40] Brandoni Caterina, Polonara Fabio. The role of municipal energy planning in the regional energy-planning process. Energy 21 July 2012 ISSN: 0360 5442. http://dx.doi.org/10.1016/j.energy.2012.06.061. Available online.

[41] Möller Bernd, Sperling Karl, Nielsen Steffen, Smink Carla, Kerndrup Søren. Creating consciousness about the opportunities to integrate sustainable energy on islands. Energy 4 May 2012 ISSN: 0360-5442. http://dx.doi.org/ 10.1016/j.energy.2012.04.008. Available online.
[42] Ajanovic Amela, Schipper Lee, Haas Reinhard. The impact of more efficient but larger new passenger cars on energy consumption in EU-15 countries. Energy 28 June 2012 ISSN: 0360-5442. http://dx.doi.org/10.1016/j.energy.2012.05.039. Available online.

[43] Hedegaard Karsten, Ravn Hans, Juul Nina, Meibom Peter. Effects of electric vehicles on power systems in Northern Europe. Energy 6 July 2012 ISSN: 0360-5442. http://dx.doi.org/10.1016/j.energy.2012.06.012. Available online.

[44] Metz Michael, Doetsch Christian. Electric vehicles as flexible loads - a simulation approach using empirical mobility data. Energy 30 April 2012 ISSN: 03605442. http://dx.doi.org/10.1016/j.energy.2012.04.014. Available online.

[45] Ko Chun-Han, Yeh Kai-Wun, Wang Ya-Nang, Wu Chien-Hou, Chang FangChih, Cheng Ming-Hsun, et al. Impact of methanol addition strategy on enzymatic transesterification of jatropha oil for biodiesel processing. Energy 20 July 2012 ISSN: 0360-5442. http://dx.doi.org/10.1016/j.energy.2012.06.042. Available online.

[46] Zhang HL, Baeyens J, Tan TW. Mixing phenomena in a large-scale fermenter of starch to bio-ethanol. Energy 13 June 2012 ISSN: 0360-5442. http:// dx.doi.org/10.1016/j.energy.2012.05.015. Available online.

[47] Hájek Martin, Skopal František, Capek Libor, Černoch Michal, Kutálek Petr. Ethanolysis of rapeseed oil by $\mathrm{KOH}$ as homogeneous and as heterogeneous catalyst supported on alumina and CaO. Energy 20 July 2012 ISSN: 03605442. http://dx.doi.org/10.1016/j.energy.2012.06.052. Available online.

[48] Irsag Bojan, Pukšec Tomislav, Duić Neven. Long term energy demand projection and potential for energy savings of Croatian tourism-catering trade sector. Energy 20 August 2012 ISSN: 0360-5442. http://dx.doi.org/10.1016/ j.energy.2012.06.069. Available online.

[49] Peri Giorgia, Traverso Marzia, Finkbeiner Matthias, Rizzo Gianfranco. The cost of green roofs disposal in a life cycle perspective: covering the gap. Energy 26 March 2012 ISSN: 0360-5442. http://dx.doi.org/10.1016/j.energy.2012.02.045. Available online.

[50] Oliveira Henriques C, Henggeler Antunes C. Interactions of economic growth, energy consumption and the environment in the context of the crisis - a study with uncertain data. Energy 10 May 2012 ISSN: 0360-5442. http://dx.doi.org/ 10.1016/i.energy.2012.04.009. Available online.

[51] Cantore Nicola. Sustainability of the energy sector in the Mediterranean region. Energy 27 July 2012 ISSN: 0360-5442. http://dx.doi.org/10.1016/ j.energy.2012.06.019. Available online.

[52] Paleta Rita, Pina André, Silva Carlos A. Remote autonomous energy systems project: towards sustainability in developing countries. Energy 18 July 2012 ISSN: 0360-5442. http://dx.doi.org/10.1016/j.energy.2012.06.004. Available online.

Brian Vad Mathiesen*

Department of Development and Planning, Aalborg University, A. C. Meyers Vænge 15, DK-2450 Copenhagen SV, Denmark

Neven Duić ${ }^{1}$

Department of Energy, Power Engineering and Environment, Faculty of Mechanical Engineering and Naval Architecture, University of Zagreb, Ivana Lučića 5, 10000 Zagreb, Zagreb, Croatia E-mail address: Neven.Duic@fsb.hr (N. Duić)

Ingo Stadler, Prof. Dr.-Ing. habil. Cologne University of Applied Sciences, Institute of Electrical Power Engineering, Betzdorferstr. 2, 50679 Cologne, Germany E-mail address: ingo.stadler@fh-koeln.de (I. Stadler)

Gianfranco Rizzo, Prof. Department of Energy, Università degli Studi di Palermo, Viale delle Scienze, Building 9, 90128 Palermo, Italy

E-mail address: gianfranco.rizzo@unipa.it (G. Rizzo)

Zvonimir Guzović ${ }^{2}$

Department of Energy, Power Engineering and Environment, Faculty of Mechanical Engineering and Naval Architecture, University of Zagreb, Ivana Lučića 5, 10000 Zagreb, Zagreb, Croatia E-mail address: zvonimir.guzovic@fsb.hr

* Corresponding author. Tel.: +45 99407218. E-mail address: bvm@plan.aau.dk (B.V. Mathiesen)

Available online $\mathrm{xxx}$

1 Tel.: +38591 5285443; fax: +38516156940

Tel.: +38591 5187446; fax: +38516156940. 